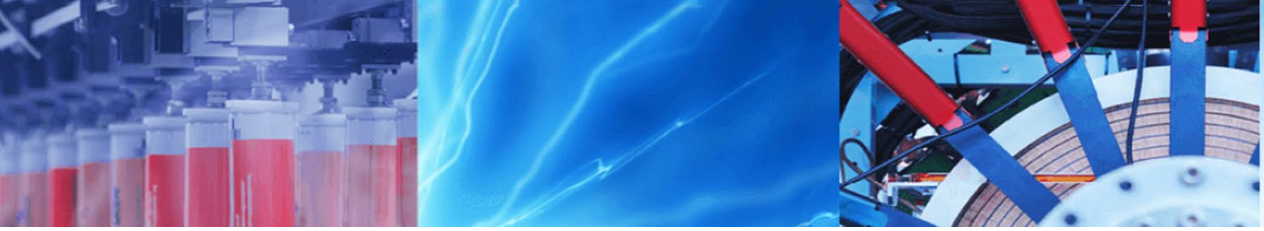

Research Article

\title{
Spatial distribution and toxicity potential of gaseous criteria air pollutants in the ambient air around a typical haulage truck stop
}

\author{
Mayowa Adeoye Lala ${ }^{1}$. Olusola Adedayo Adesina ${ }^{1} \cdot$ Lekan Taofeek Popoola $^{1}$. John Olusoji Owolabi ${ }^{1}$. \\ Babatunde Oyeleke Oyewale ${ }^{2}$
}

(c) Springer Nature Switzerland AG 2019

\begin{abstract}
This study investigated the spatial distribution and toxicity potential of gaseous criteria air pollutants in the ambient air around a typical haulage truck stop. ToxiRAE II Gas Monitors were used to monitor ambient concentrations of the criteria pollutants both for dry season and wet season. Five sampling points were considered, and a control sampling point was set at about $55 \mathrm{~km}$ away from the influence of activities of the truck stop. The results showed the dry season average 24-h concentrations of $\mathrm{NO}_{2}$ with the range of $0.064-0.335 \mathrm{ppm}$ while $\mathrm{CO}$ ranged between 0.919 and $4.911 \mathrm{ppm}$. During the wet season, the average concentrations of $\mathrm{NO}_{2}$ ranged between 0.003 and $0.052 \mathrm{ppm}$, while $\mathrm{CO}$ concentration ranged between 0.000 and $4.798 \mathrm{ppm}$. The result showed average concentration of $\mathrm{CO}$ at all sampling points for both dry and wet season was below the Nigerian Federal Ministry of Environment (FEPA) national air quality standard of 10 ppm. However, average concentration of $\mathrm{NO}_{2}$ at all sampling points during the dry season were above FEPA and World Bank air quality standards except sampling point $D$. The results also showed the toxicity potential which exceeded unity at some of the designated sampling points is of major concern especially among people with respiratory or heart disease. The study showed the haulage truck stop contributes greatly to the ambient gaseous criteria air pollutants.
\end{abstract}

Keywords Air quality standards $\cdot$ Gaseous criteria air pollutants $\cdot$ Toxicity potential $\cdot$ Haulage truck stop $\cdot$ Spatial distribution

\section{Introduction}

Wide range of adverse health, environmental and climatic effects attributed to air pollution has been of a great concern. Among the most common air pollutants are carbon monoxide (CO), nitrogen dioxide $\left(\mathrm{NO}_{2}\right)$, particulate matter $(\mathrm{PM})$, sulfur dioxide $\left(\mathrm{SO}_{2}\right)$, lead $(\mathrm{Pb})$ and ground-level ozone $\left(\mathrm{O}_{3}\right)$ known as criteria pollutants. These pollutants are present in ambient air generally due to numerous natural or man-made sources of emissions. Anthropogenic sources of air pollution remain a major contributor to ambient air pollution level $[7,18,23]$; this includes combustion processes that occur in automobiles engine, bush burning, electricity generating plants, decaying of accumulated organic and domestic wastes, and other industrial processes [5]. Apart from particulate matter (PM) and volatile organic compounds (VOCs), emissions from automobile exhaust contain a wide variety of carbon monoxide (CO) and nitrogen dioxide $\left(\mathrm{NO}_{2}\right)$ which have a long-term impact on air quality [1].

Pollutants adverse effects on human health and welfares are enormous about 2.4 million people die every year

Electronic supplementary material The online version of this article (https://doi.org/10.1007/s42452-019-0373-z) contains supplementary material, which is available to authorized users.

Olusola Adedayo Adesina, adesinaolusola50@yahoo.com | ${ }^{1}$ Department of Chemical and Petroleum Engineering, Afe Babalola University, Ado Ekiti, Nigeria. ${ }^{2}$ Environmental Engineering Research Laboratory, Department of Chemical Engineering, Obafemi Awolowo University, Ile-Ife, Nigeria.

SN Applied Sciences (2019) 1:369| https://doi.org/10.1007/s42452-019-0373-z

Received: 30 October 2018 / Accepted: 18 March 2019 / Published online: 27 March 2019 
due to air pollution $[2,26]$. CO, a major product of incomplete combustion, is a colorless, odorless, highly toxic and non-irritating poisonous gas [11,22], could enter the bloodstream through the lungs impair the hemoglobin on the red blood cell from caring oxygen to all parts of the body and may lead to dizziness, poor learning ability, reduced work capacity, difficulty in performing complex tasks and can also cause death at higher concentration level of exposure $[10,12,19,21,24]$. $\mathrm{NO}_{2}$ which is one of the highly reactive nitrogen oxides $\left(\mathrm{NO}_{\mathrm{x}}\right)$ causes serious health effects, contributes to acid rain, haze and affects water quality [17]. The major source of $\mathrm{NO}_{2}$ is from motor vehicle exhaust; other sources include petrol and metal refining, electricity generation from coal-fired power stations and manufacturing industries [10].

Haulage vehicle parks are characterized by fleet of heavy duty vehicles, the activities of these vehicles such as their movement in and out of the park, engine idling, and cold start are sources of ambient air pollution [6]. The major function of the park is to provide refuelling, rest and other services to motorists and truck drivers [13]. However due to large number of trucks, there could be breach of ambient air quality standards from massive exhaust emissions which could have health impact on the host community.

Air quality assessment through toxicity potential ( $\left.T_{\text {potential }}\right)$ expresses the potential harm of a unit of pollutant released into the ambient air [3]. $T_{\text {potential }}$ computed from the ratio of measured pollutant concentration to the statutory limit set for such pollutant becomes worrisome when the value exceeds unity $[15,20]$. Studies on $T_{\text {potential }}$ of criteria pollutants have revealed concerns associated with the exposures to such pollutants [14, 16]. This study investigated the toxicity potential of gaseous criteria air pollutants in the ambient air of a haulage vehicle park using $\mathrm{CO}$ and $\mathrm{NO}_{2}$ as indicators. The National Air Quality Standards of Nigeria Federal Ministry of Environment and World Bank standards were used as the statutory limit set for the pollutants considered.

\section{Methodology}

\subsection{Study area}

The study area is a typical haulage truck park located along kilometer 56 Lagos-lbadan dual carriage highway, Ogere, Ogun State of Southwestern part of Nigeria. The park is situated on geographical coordinate $6^{\circ} 56^{\prime} 0^{\prime \prime}$ north and $3^{\circ} 38^{\prime} 0^{\prime \prime}$ east. The park is about $0.6 \mathrm{~km}^{2}$ area, and this area is the major commercial center of the community. Ogere haulage truck stop is located along the major route connecting Lagos, the economic and commercial capital of
Nigeria to Northern and other parts of Nigeria. It serves as a major stop-over for haulage vehicles plying the highway. Five strategic sampling points were chosen based on the wind direction and number of parked trucks. Figure 1 shows the map of the study area with sampling point. Control sampling point $\left(R_{\text {point }}\right)$ was located at kilometer 55 outside the haulage vehicle park region to allow for comparison with air quality under the influence of haulage vehicle activities obtained. Sampling point $A$ was located at the entrance of the park, sampling point $B$ was located along the highway, and sampling point $C$ catered for the emission monitoring from the park along the highway. Sampling points $D$ and $E$ were located in the two major sub-parks (Maigari Park) and (Gateway Park), respectively.

\subsection{Sampling procedure}

Sampling of the selected gaseous criteria air pollutants in the ambient air of the haulage vehicle park was carried out for dry season and wet season as humidity influences thermal and photochemical reactions in the atmosphere [9]. For each season, concentrations of $\mathrm{CO}$ and $\mathrm{NO}_{2}$ were quantified for 8-h averaging period with sampling frequency of $20 \mathrm{~min}$ for three (3) consecutive days at each designated sampling point. Five identical samplers were used the same time to monitor the gases. Ambient concentrations of $\mathrm{NO}_{2}$ and $\mathrm{CO}$ were determined using firmware version 1.0 ToxiRAE II Gas Monitors of each of the gaseous pollutants. The monitors can measure a continuous and digital display of the gas concentrations in part per million (ppm). They have facility for short-term exposure limit (STEL) of $1 \mathrm{ppm}$ and $100 \mathrm{ppm}$, time-weighted average (TWA) of 1

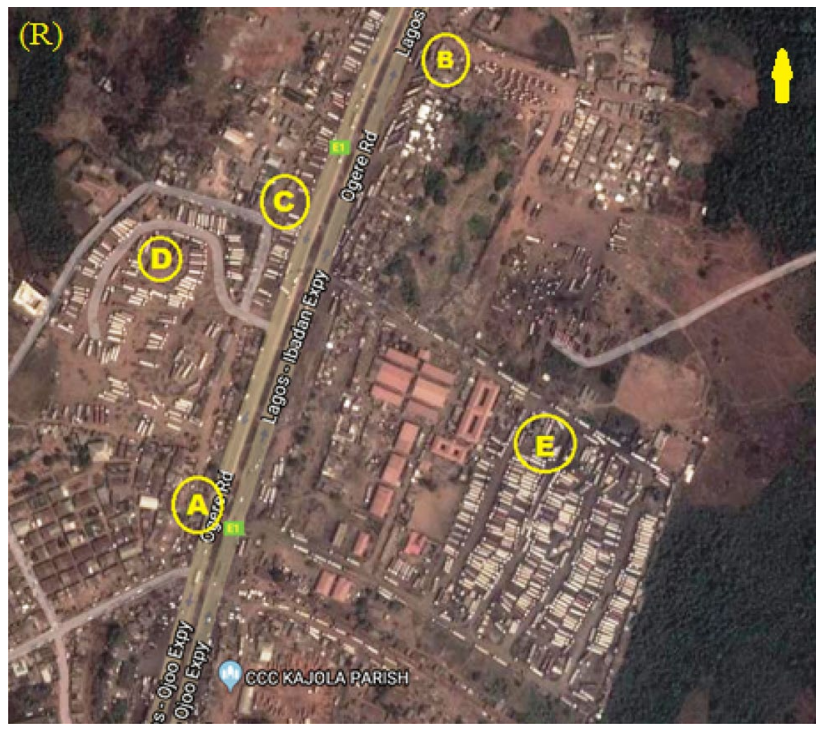

Fig. 1 The studied area in Ogere with location of the sampling points, Ogun State, Nigeria 
and $35 \mathrm{ppm}$, for $\mathrm{NO}_{2}$ and $\mathrm{CO}$, respectively. Also, $\mathrm{NO}_{2}$ has sensitivity ranges of $0-20 \mathrm{ppm}$ with lowest detection limit of $0.01 \mathrm{ppm}$ and $\mathrm{CO}$ sensitivity range is $0-500 \mathrm{ppm}$. The Gas concentrations were measured at a height close to that of the human respiratory system. Meteorological parameters were also measured using Kestrel 4000 Pocket Weather Tracker. Contour maps were created for the pollutants using geostatistical interpolation technique with ordinary Kriging algorithm. This was carried out with Golden Software Surfer 13.0 (USA). The 8-h averaging period sampled concentration data were extrapolated to 24-h averaging period using Eq. (1), an atmospheric stability dependent equation.

$C_{0}=C_{1} \times\left(\frac{T_{1}}{T_{0}}\right)^{n}$

where $C_{0}$ is the shorter averaging time concentration, $C_{1}$ is the longer averaging time concentration, $T_{1}$ is the longer averaging time, $T_{0}$ is shorter averaging time, and $n$ is the stability-dependent exponent given as $0.28[4,6]$.

\subsection{Toxicity potential}

Toxicity potential ( $\left.T_{\text {potential }}\right)$ of the criteria air pollutants was calculated using Eq. (1), where $M_{\mathrm{PC}}$ is the measured pollutant concentration and $S_{\text {limit }}$ is the statutory limit set for such pollutant. The National Air Quality Standards of the Federal Ministry of Environment [8] and World Bank standard [25] statutory limit were used for the study (Table 1).

$T_{\text {potential }}=\left(\frac{M_{\mathrm{pc}}}{S_{\text {limit }}}\right)$

\section{Results and discussion}

Table 2 summarizes the overall measured average concentrations (8-h averaging period) of air pollutants at the sampling points $A, B, C, D$, and $E$ for dry and wet seasons. $\mathrm{NO}_{2}$ concentration ranged from 0.088 to $0.456 \mathrm{ppm}$ with an average of $0.249 \mathrm{ppm}$, while CO ranged from 1.250 to $6.681 \mathrm{ppm}$ with an average of $4.383 \mathrm{ppm}$ for dry season

Table 1 Ambient air quality standards. Source: WHO [25, 27]

\begin{tabular}{lll}
\hline Air pollutants & \multicolumn{2}{l}{ Concentrations (ppm) } \\
\cline { 2 - 3 } & FEPA & World Bank \\
\hline $\mathrm{NO}_{2}$ & $0.04-0.06$ & 0.08 \\
$\mathrm{CO}$ & 10 & - \\
\hline
\end{tabular}

Table 2 Average sampled 8-h concentration during the study

\begin{tabular}{llllll}
\hline$S_{\text {point }}$ & \multicolumn{2}{l}{ Gaseous pollutants } & & \\
\cline { 2 - 3 } & \multicolumn{2}{l}{ Dry season } & & & \multicolumn{2}{l}{ Rainy season } \\
\cline { 2 - 3 } \cline { 5 - 6 } & $\mathrm{NO}_{2}(\mathrm{ppm})$ & $\mathrm{CO}(\mathrm{ppm})$ & & $\mathrm{NO}_{2}(\mathrm{ppm})$ & $\mathrm{CO}(\mathrm{ppm})$ \\
\hline$A$ & 0.233 & 5.875 & & 0.019 & 6.028 \\
$B$ & 0.456 & 6.681 & & 0.012 & 4.375 \\
$C$ & 0.246 & 6.486 & & 0.004 & 6.528 \\
$D$ & 0.088 & 1.250 & & 0.064 & 0.000 \\
$E$ & 0.222 & 1.624 & & 0.071 & 0.833 \\
$C_{\text {point }}$ & 0.000 & 0.000 & 0.000 & 0.000 \\
\hline
\end{tabular}

period. Also, concentrations ranged between 0.004 and $0.071 \mathrm{ppm}$ with an average concentration of $0.034 \mathrm{ppm}$ for $\mathrm{NO}_{2}$ and $\mathrm{CO}$ ranged from 0.000 to $6.528 \mathrm{ppm}$ with an average concentration of $3.553 \mathrm{ppm}$ during wet season. Summarized in Table SM1 and SM2 of the supplementary material show the average concentrations of air pollutants while $\mathrm{SM} 3$ shows maximum concentration $\mathrm{NO}_{2}$ quantified for the 3 consecutive days. When compared, the extrapolated $24-\mathrm{h}$ averaging period pollutants concentration for the study region given in Table 3 with FEPA and World Bank air quality standards presented in Table 1, average concentrations of $\mathrm{CO}$ at all sampling points and control sampling point for both dry and wet season were below the FEPA National air quality standard of $10 \mathrm{ppm}$. However, the average concentrations of $\mathrm{NO}_{2}$ at all sampling points during the dry season were above FEPA and World Bank air quality standards except sampling point $D$ that was below the World Bank standard. Extrapolated values for the wet season were below the standards except for sampling points $D$ and $E$ that are slightly above the lower limit of FEPA standard.

Table 3 Extrapolated 24-h averaging period pollutants' concentration for the study

\begin{tabular}{llllll}
\hline$S_{\text {point }}$ & \multicolumn{2}{l}{ Gaseous pollutants } & & \\
\cline { 2 - 3 } & \multicolumn{2}{l}{ Dry season } & & & \multicolumn{2}{l}{ Rainy season } \\
\cline { 2 - 3 } \cline { 5 - 6 } & $\mathrm{NO}_{2}(\mathrm{ppm})$ & $\mathrm{CO}(\mathrm{ppm})$ & & $\mathrm{NO}_{2}(\mathrm{ppm})$ & $\mathrm{CO}(\mathrm{ppm})$ \\
\hline$A$ & 0.172 & 4.318 & & 0.014 & 4.431 \\
$B$ & 0.335 & 4.911 & & 0.009 & 3.216 \\
$C$ & 0.181 & 4.767 & & 0.003 & 4.798 \\
$D$ & 0.064 & 0.919 & & 0.047 & 0.000 \\
$E$ & 0.163 & 1.194 & & 0.052 & 0.612 \\
$C_{\text {point }}$ & 0.000 & 0.000 & 0.000 & 0.000
\end{tabular}




\subsection{Spatial and seasonal variations}

Figure 2a-d shows contour maps of spatial distribution of the gaseous pollutants during the wet and dry seasons. The color legend in the map depicts the different concentration ranges of the pollutants in the study area. The increasing intensity of red denotes higher concentrations, while increasing intensity of blue depicts lower concentrations. Figure $2 \mathrm{a}, \mathrm{b}$ shows the spatial distributions for dry and wet season; a distinct difference in the spatial pattern was observed for both seasons. Sampling point B is located at the center of the park where largest number of truck is parked and this could be associated with the highest concentration of $\mathrm{NO}_{2}$ observed at the point in dry season; also the average Meteorological Parameter of the Study Area (Table 4) showed the average wind direction northern easterly which blows the pollutants from other sampling points to point $B$. However, there is a change in the wind direction to southwestern wind in the wet season which blows the pollutant toward sampling points $C$ and D. Also hydrological condition in the wet season could be responsible for the relatively low concentrations of $\mathrm{NO}_{2}$ as the pollutant emitted are easily washed down to the ground. The trend shown in Fig. $2 c$, d revealed that wind a

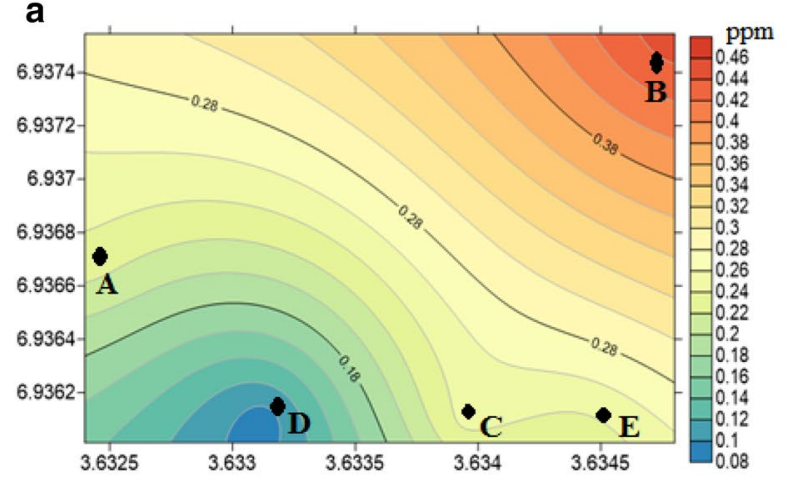

C

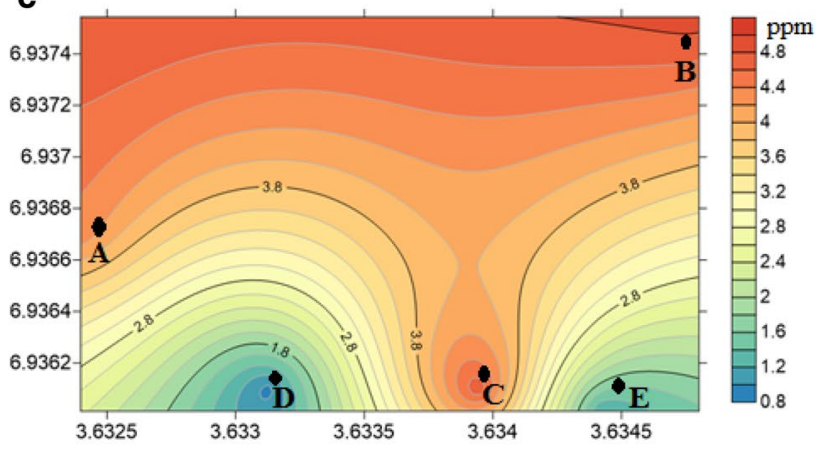

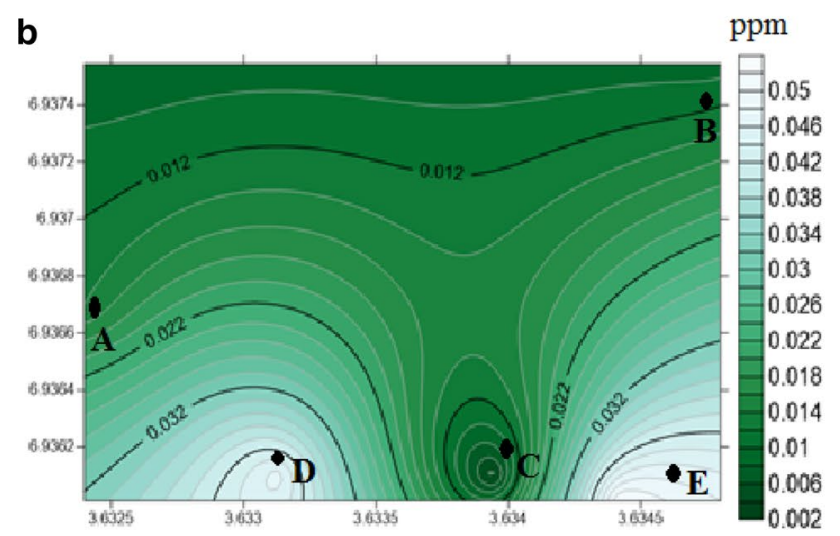

d

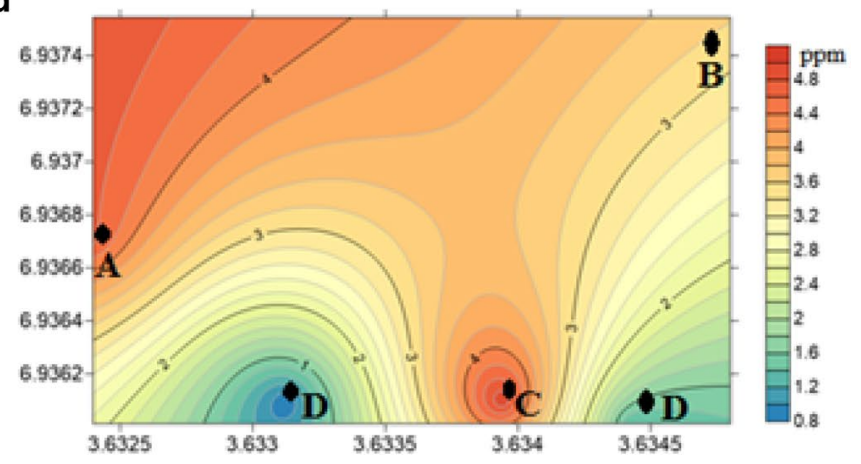

Fig. 2 Contour maps of spatial distribution of the gaseous pollutants. a $\mathrm{NO}_{2}$ dry season, $\mathbf{b} \mathrm{NO}_{2}$ wet season, $\mathbf{c} \mathrm{CO}$ dry season, $\mathbf{d}$ CO wet season

Table 4 Average meteorological parameter of the study area

\begin{tabular}{|c|c|c|c|c|c|c|c|c|}
\hline \multirow[t]{3}{*}{$S_{\text {point }}$} & \multicolumn{8}{|c|}{ Meteorological parameter } \\
\hline & \multicolumn{5}{|l|}{ Dry season } & \multicolumn{3}{|c|}{ Rainy season } \\
\hline & $\begin{array}{l}\text { Relative } \\
\text { humidity (\%) }\end{array}$ & Temp. ${ }^{\circ} \mathrm{C}$ & $\begin{array}{l}\text { Wind speed } \\
(\mathrm{m} / \mathrm{s})\end{array}$ & Wind direction & $\begin{array}{l}\text { Relative } \\
\text { humidity (\%) }\end{array}$ & Temp. $\left({ }^{\circ} \mathrm{C}\right)$ & $\begin{array}{l}\text { Wind speed } \\
(\mathrm{m} / \mathrm{s})\end{array}$ & Wind direction \\
\hline$A$ & 50.79 & 32.21 & 0.74 & N55E & 61.08 & 30.12 & 0.69 & S50W \\
\hline$B$ & 51.04 & 32.54 & 0.71 & N55E & 62.26 & 29.18 & 0.95 & S50W \\
\hline C & 51.08 & 32.75 & 0.68 & N53E & 58.50 & 33.06 & 1.12 & S55W \\
\hline$D$ & 47.80 & 31.91 & 0.69 & N45E & 64.12 & 28.66 & 1.01 & S45W \\
\hline E & 50.17 & 33.90 & 0.76 & N50E & 73.30 & 27.54 & 0.41 & S45W \\
\hline
\end{tabular}


Table 5 Dry season computed $T_{\text {potential }}$ for the study

\begin{tabular}{llllll}
\hline$S_{\text {point }}$ & $\mathrm{NO}_{2}$ & & & $\mathrm{CO}$ \\
\cline { 2 - 3 } & $\begin{array}{l}\text { FEPA (lower } \\
\text { limit) }\end{array}$ & $\begin{array}{l}\text { FEPA (upper } \\
\text { limit) }\end{array}$ & & Word Bank & FEPA \\
\hline$A$ & 4.300 & 2.867 & 2.150 & 0.432 \\
$B$ & 8.375 & 5.583 & & 4.188 & 0.491 \\
$C$ & 4.525 & 3.017 & & 2.263 & 0.477 \\
$D$ & 1.600 & 1.067 & & 0.800 & 0.092 \\
$E$ & 4.075 & 2.717 & 2.038 & 0.119 \\
$C_{\text {point }}$ & 0.000 & 0.000 & 0.000 & 0.000 \\
\hline
\end{tabular}

Table 6 Wet season computed $T_{\text {potential }}$ for the study

\begin{tabular}{llllll}
\hline$S_{\text {point }}$ & $\mathrm{NO}_{2}$ & & & $\mathrm{CO}$ \\
\cline { 2 - 3 } \cline { 5 - 6 } \cline { 5 - 6 } & $\begin{array}{l}\text { FEPA (lower } \\
\text { limit) }\end{array}$ & $\begin{array}{l}\text { FEPA (upper } \\
\text { limit) }\end{array}$ & & Word Bank & FEPA \\
\hline$A$ & 0.350 & 0.233 & 0.175 & 0.443 \\
$B$ & 0.225 & 0.150 & & 0.113 & 0.322 \\
$C$ & 0.075 & 0.050 & & 0.038 & 0.480 \\
$D$ & 1.175 & 0.783 & 0.588 & 0.000 \\
$E$ & 1.300 & 0.867 & 0.650 & 0.061 \\
$C_{\text {point }}$ & 0.000 & 0.000 & 0.000 & 0.000 \\
\hline
\end{tabular}

direction and hydrological condition did not affect the distribution of $\mathrm{CO}$ for the both seasons; this could be due to precursor nature of the compound, as carbon monoxide could be spontaneously oxidized by air to carbon dioxide in the presence of ultraviolet light.

\subsection{Toxicity potential}

Summarized in Tables 5 and 6 are computed $T_{\text {potentials }}$ from the 24-h extrapolated averaging period concentration and 24-h air quality standards given by FEPA and World Bank. Considering the five sampling points, $\mathrm{NO}_{2} T_{\text {potential }}$ for dry season ranged from 1.600 to $8.375,1.067$ to 5.583 and 0.800 to 4.188 for FEPA lower limit, FEPA upper limit and World Bank standard, respectively, while CO $T_{\text {potential }}$ for same dry season ranged from 0.092 to 0.491 for FEPA. $\mathrm{NO}_{2} T_{\text {potential }}$ for wet season was of the range $0.075-1.175$, 0.050-0.867 and 0.038-0.650 for FEPA lower limit, FEPA upper limit and World Bank standard, respectively, while CO $T_{\text {potential }}$ for same wet season was of the range $0.000-0.480$. CO $T_{\text {potential }}$ for rainy season in all the sampling points remains below the unity value of 1.000 and similarly, $\mathrm{NO}_{2} T_{\text {potential }}$ for wet season was all below unity except $S_{\text {point }} D$ and $S_{\text {point }} E$ when lower limit of FEPA was considered. Therefore, the sampling region is generally safe with no cause for concern during the wet season, as combination of rainfall and high wind speed during this season in some cases significantly improves air quality. Also, the $T_{\text {potential }}$ value above unity at $S_{\text {point }} D$ and $S_{\text {point }} E$ is of little or no concern because the region is always free of commercial and domestic activities.

During dry season, ambient air of the sampling region is safe with no cause for concern with respect to $\mathrm{CO}$ as the $T_{\text {potential }}$ for all sampling points is less than unity (Table 6). However, $T_{\text {potentials }}$ computed for $\mathrm{NO}_{2}$ during dry season (Table 6) indicates a great cause for concern as exposure can aggravate heart or lung diseases leading to respiratory problems symptoms and increase premature mortality in persons with cardiopulmonary disease, children and the elderly [19]. Results computed in Table 6 also indicate that more potential harm is attributed to region around $S_{\text {point }} A$, $S_{\text {point }} B$ and $S_{\text {point }} C$ because $T_{\text {potentials }}$ obtained are greatly above unity and these parts of the sampling region are the main commercial and domestic part of the haulage vehicle park. Therefore, pollution control measures should be put in place in these regions.

\section{Conclusion}

Spatial distribution as well as Toxicity Potential of the ambient air around a typical haulage vehicle stop was investigated in this study. ToxiRAE II Gas Monitor was used to monitor concentrations of $\mathrm{NO}_{2}$ and $\mathrm{CO}$ in the ambient air around the haulage truck stop. National Air Quality Standards of FEPA and World Bank standards were used to compute toxicity potentials. Dry season extrapolated concentrations of $\mathrm{NO}_{2}$ for the study region ranged between 0.064 and $0.335 \mathrm{ppm}$ and $\mathrm{CO}$ ranged between 0.919 and $4.911 \mathrm{ppm}$, while wet season extrapolated concentrations of $\mathrm{NO}_{2}$ ranged between 0.003 and $0.052 \mathrm{ppm}$ and $\mathrm{CO}$ concentrations ranged between 0.000 and 4.798 ppm. Extrapolated average concentration of $\mathrm{NO}_{2}$ at all sampling point during dry season breached FEPA and World Bank standards except sampling point $D$ that is below the World Bank standard, while values for the rainy season were below the standards excepted sampling points $D$ and $E$ that are slightly above the lower limit of FEPA standard. Toxicity Potential exceeding unity at some of the designated sampling points calls for major concern especially among people with respiratory or heart disease, the elderly and children, and the results computed indicated that more potential harm is attributed to region around sampling points $A, B$ and $C$.

\section{Compliance with ethical standards}

Conflict of interest The authors declare that they have no conflict of interest. 


\section{References}

1. Abam FI, Unachukwa GO (2009) Vehicular emissions and air quality standards in Nigeria. Eur J Sci Res 34:550-560

2. Abu-Allaban M, Abu-Qudais H (2011) Impact assessment of ambient air quality by cement industry: a case study in Jordan. Available via DIALOG. https://doi.org/10.4209/ aaqr.2011.07.0090. Accessed 12 Sept 2018

3. Ayodele CO, Fakinle BS, Jimoda LA, Sonibare JA (2016) Investigation on the ambient air quality in a hospital environment. Cogent Environ Sci 2:1215281

4. Bashar MA, Kamel KA, Khaldoun MS (2009) Assessment of air pollutants emissions from a cement plant: a case study in Jordan. Jordan J Civil Eng 3(3):265-282

5. Dara SS (2000) Textbook of environmental chemistry and pollution control. S. Chad Co. Ltd, New Delhi

6. Fakinle BS, Sonibare JA, Akeredolu FA, Okedere OB, Jimoda LA (2013) Toxicity potential of particulates in the airshed of haulage vehicle park. Glob NEST J 15:466-473

7. Fakinle BS, Sonibare JA, Okedere OB, Jimoda LA, Ayodele CO (2016) Air quality index pattern of particulate around a haulage vehicle park. Cogent Environ Sci 34(1):1-7

8. Federal Environmental Protection Agency, Nigeria (FEPA) (1991) Guidelines and standards for environmental pollution control in Nigeria, pp 33-103

9. Gaffney JS, Marley NA (2016) Atmospheric chemistry and air pollution. Sci World J 7(3):199-234

10. Han X, Naeher LP (2006) A review of traffic-related air pollution exposure assessment studies in the developing world. Environ Int 2006(32):106-120

11. Hickey N, Boscarato I, Kaspar J (2014) Air pollution from mobile sources: formation and effects. Abatement strategies. Available via DIALOG. https://doi.org/10.1007/978-94-017-8777-2. Accessed 12 Sept 2018

12. Occupational Safety in Health Administration (U.S. OSHA) (2002) Fact sheet: carbon monoxide poisoning. Departmental of Labor. Available via DIALOG. http://www/osha.gov/oshDoc/data/general.facts/carbonmonoxide-factsheet.pdf. Accessed 12 Sept 2018

13. Oketola AA, Osibanjo O (2011) Assessment of industrial pollution load in Lagos, Nigeria by industrial pollution projection system (IPPS) versus effluent analysis. Environmental Management in Practice, 978-953-307-358-3

14. Otto $S$, de Reus M, Trautmann T, Thomase A, Wendisch M, Borrmann S (2007) Atmospheric radiative effects of an in situ measured Saharan dust plume and the role of large particles. Atmos Chem Phys 7:4887-4903

15. Owoade OK, Olise FS, Obioh IB, Olaniyi HB, Ferrero L, Bolzacchini E (2009) ED-XRF elemental assay of airborne particulates: a case study of an iron and steel smelting industry, Lagos, Nigeria. Sci Res Essay 4(11):1342-1347

16. Sacks JD, Stanek LW, Luben TJ, Johns DO, Buckley BJ, Brown JS (2010) Particulate matter induced health effect: Who is susceptible? Environ Health Perspect 119:446-454

17. Satoshi N, Eldred TT (2012) Monitoring the levels of toxic air pollutants in the ambient air of Freetown, Sierra Leone. Afr J Environ Sci Technol 6(7):283-292

18. Shukla JB, Misra AK, Sundar S, Naresh R (2008) Effect of rain on removal of a gaseous pollutant and two different particulate matters from the atmosphere of a city. Math Comput Model 48:832-844

19. Sonibare JA, Adebiyi FM, Obanijesu EO, Okelana OA (2010) Air quality index pattern around petroleum production facilities. Int J Manag 21:379-392. https://doi.org/10.1108/1477783101 1036920

20. Sonibare JA, Akeredolu FA, Osibanjo O, Latinwo I (2005) ED$\mathrm{XRF}$ analysis of total suspended particulates from enamelware manufacturing industry. Am J Appl Sci 2:573-578

21. U.S. Environmental Protection Agency (U.S. EPA) (2006) Backyard burning-human health effect. Available via DIALOG. http:// www.epa.gov/garbage/backyard/health.htm. Accessed 12 Sept 2018

22. U.S. Environmental Protection Agency (U.S. EPA) (2010) Integrated science assessment for carbon monoxide (final report). National Center for Environmental Assessment, 2010, EPA/600/ R-09/019F. Available via DIALOG. http://cfpub.epa.gov/ncea/ $\mathrm{cfm} /$ recordisplay.cfm?deid=218686. Accessed 12 Sept 2018

23. Udia C (2005) The environmental pollution consequences of the Niger Delta Wetland occasioned by gas flaring. J Land Use Dev Stud 1:12-20

24. Varon J, Marik E, Fromm E, Gueler A (1999) Carbon monoxide poisoning: a review for clinicians. J Emerg Med 17:87-93

25. World Bank (1999) Pollution prevention and abatement handbook 1998: toward cleaner production. World Bank, New York

26. World Health Organization (2007) Estimated Deaths \& DALYs attributable to selected environmental risk factors, by WHO Member State, 2002. Department of Public Health \& Environment. January 2007

27. World Health Organization (WHO) (2015)WHO methods and data sources for global causes of death 2000-2012. Global health estimates technical paper, 2014. Available via DIALOG. http://www.who.int/entity/healthinfo/global_burden_disease/ GlobalCOD_method_2000_2012. Accessed 12 Sept 2018

Publisher's Note Springer Nature remains neutral with regard to jurisdictional claims in published maps and institutional affiliations. 